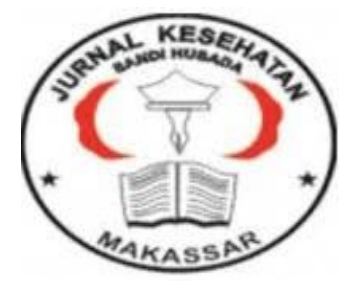

Jurnal Ilmiah Kesehatan Sandi Husada

hhttps://akper-sandikarsa.e-journal.id/JIKSH

Volume 9, Nomor 2, Desember 2020, pp 897-901

p-ISSN: 2354-6093 dan e-ISSN: 2654-4563

DOI: $10.35816 /$ jiskh.v10i2.425

\title{
Pengaruh Kualitas Tidur Terhadap Kejadian Kejang Pada Pasien Epilepsi
}

Effect of Sleep Quality on the Incidence of Seizures in Epilepsy Patients

\section{Dansen Frans Louise Draven Rudyanto}

Fakultas Kedokteran Universitas Lampung

\section{Artikel info}

Artikel history:

Received; Juli 2020

Revised: Agustus 2020

Accepted; September 2020

\begin{abstract}
Abstrak
Latar Belakang: Epilepsi adalah suatu kondisi dimana terjadinya gangguan neurologik yang paling sering ditemui. Pada negara berkembang, insidensi epilepsi lebih tinggi dari negara maju. Kejadian kejang pada epilepsi dapat dikurangi dengan pengobatan yang teratur akan tetapi tidak sedikit juga yang mengalami kejadian kejang berulang, hal ini dapat dipengaruhi beberapa faktor selain pengobatan yang tidak teratur. Salah satu faktornya adalah pengaruh dari kualitas tidur. Tujuan: Mengetahui lebih lanjut pengaruh kualitas tidur terhadap kejadian kejang pada epilepsy. Metode: Menggunakan studi literatur dari 2 jurnal nasional dan 2 jurnal internasional. Kesimpulan: Terdapat pengaruh kualitas tidur terhadap kejadian kejang pada pasien epilepsi.
\end{abstract}

\section{Abstract}

Background: Epilepsy is the most common neurological disorder. In developing countries, the incidence of epilepsy is higher than in developed countries. The incidence of seizures in epilepsy can be reduced with regular treatment, but not a few who experience recurrent seizures, this can be influenced by several factors other than irregular treatment. One of the factors is the influence of sleep quality. Objective: To find out more about the effect of sleep quality on the incidence of seizures in epilepsy. Methods: Using literature studies from 2 national and international journals. Conclusion: There is an effect of sleep quality on the incidence of seizures in epileptic patients.

Keywords:

Epilepsi;

Kualitas tidur;

Kejadian kejang;
Coresponden author:

Email: dansenfrans.df@gmail.com

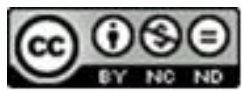

artikel dengan akses terbuka dibawah lisensi BCC BY NC ND-4.0 


\section{Pendahuluan}

Indonesia merupakan Negara dengan tingkat gangguan tidur yang relatif tetap. Menurut penelitian yang dilakukan oleh (Nur'aini et al., 2014) dengan metode cross sectional didapatkan angka 38\% untuk remaja di daerah pusat kota dan $37,7 \%$ di pinggiran kota. Menurut data WHO pada tahun 2005, terdapat 50 juta orang yang menderita epilepsi di dunia dengan prevalensi angka penderita epilepsi aktif antara 4 - 10 per 1000 penderita epilepsi sedangkan pada negara berkembang insidensi epilepsi lebih tinggi dari negara maju sekitar 100 - 190 dari 100.000 orang tiap tahun (PERDOSSI, 2014). Tidur dan epilepsi memiliki hubungan yang kompleks. Pada tahun 1900-an studi Gowers menunjukan bahwa $21 \%$ pasien dari 850 pasien mengalami kejang pada saat tidur. Pengaruh tidur terhadap epilepsi kemudian diteliti lebih lanjut menjadi tahap tidur spesifik karena discharge dari interiktal dan iktal dominan pada tidur non-rapid eye movement (NREM) dan ditekan selama tidur rapid eye movement (REM).

Pengaruh tidur juga dapat ditemui pada epilepsi benigna pada masa anak-anak, dengan centrotemporal spikes, atau autosomal dominan nokturnal lobus frontal epilepsi. Kemudian studi tersebut menemukan gangguan pada tidur akan meningkatkan frekuensi kejang (Gowers WR, 1881). Banyak faktor yang mempengaruhi terjadinya kejadian kejang epilepsi diantaranya yaitu kurang tidur, luka (jaringan parut), kelainan genetik, demam, perdarahan, tumor, keracunan alkohol, hipoksia, inflamasi, dan pembengkakan sel (Silbernagl \& Lang, 2019). Kebutuhan tidur seseorang akan berkurang seiring dengan pertambahan usia, pada usia 12 tahun kebutuhan tidur seseorang mencapai 9 jam, usia 20 tahun berkurang satu jam, usia 40 tahun berkurang satu jam lagi, 60 tahun membutuhkan 6,5 jam, dan usia 80 tahun menjadi 6 jam. Perubahan kebutuhan tidur seseorang dipengaruhi oleh faktor perubahan lingkungan sosial, konsumsi obat-obatan, suatu penyakit, dan adanya perubahan irama sirkadian (A. Prayitno, 2015).

Susah tidur telah menjadi keluhan umum yang dialami pasien epilepsi, tanpa memandang usia. Hal ini dapat berpengaruh terhadap kualitas hidup seseorang (Maganti et al., 2006). Beberapa studi mengkonfirmasi bahwa rasa kantuk saat siang hari karena kualitas tidur yang tidak baik merupakan keluhan umum (Piperidou et al., 2008). Studi yang dilakukan (Piperidou et al., 2008) prevalensi kantuk siang hari yang berlebihan sekitar 16,9\% dan yang mengalami insomnia sekitar 24,6\%, dengan faktor pencetusnya yaitu frekuensi kejang, penggunaan Obat Anti Epilepsi (OAE), dan jenis kejang. Epilepsi berasal dari bahasa Yunani, Epilambanmein yang berarti serangan. Dahulu masyarakat percaya bahwa epilepsi disebabkan oleh roh jahat dan dipercaya juga bahwa epilepsi merupakan penyakit yang bersifat suci. Hal tersebut yang mempengaruhi pandangan masyarakat sehingga menyulitkan penanganan. Epilepsi sudah ditemukan pada tahun 4000 sebelum Masehi. Ketakutan, kesalahpahaman, diskriminasi dan stigma sosial terhadap epilepsi masih berlanjut hingga sekarang di beberapa negara dapat mempengaruhi kualitas hidup bagi seseorang yang menderita dan keluarganya (WHO, 2019).

Menurut (Fisher et al., 2005), Epilepsi adalah manifestasi gangguan fungsi otak dengan gejala tunggal yang khas berupa kejang berulang akibat lepasnya muatan listrik neuron otak secara berlebihan. Serangan dapat berupa modifikasi fungsi otak yang bersifat mendadak dan sepintas, berasal dari sekelompok sel otak yang bersifat sinkron dan berirama berupa gangguan motorik, sensorik, kognitif atau psikis. Epilepsi tidak terjadi hanya sekali saja, dan bukan serangan yang terjadi selama penyakit akut berlangsung dan occasional provokes seizures misalnya kejang atau serangan pada hipoglikemia (Gardiner, 2012).

Menurut (Deliana, 2016; Shorvon, 2011), penyebab epilepsi dibagi menjadi tiga, yaitu:

1) Epilepsi primer atau epilepsi idiopatik yang penyebab pasti tidak diketahui, umumnya dikarenakan faktor genetik.

2) Epilepsi simptomatik disebabkan oleh lesi pada susunan saraf pusat, misalnya post trauma kapitis, infeksi susunan saraf pusat (SSP), gangguan metabolik, malformasi 
otak kongenital, gangguan peredaran darah otak, toksik (alkohol, obat), kelainan neurodegeneratif dan kejang demam.

3) Epilepsi kriptogenik dianggap simptomatik tetapi penyebabnya belum diketahui, termasuk disini adalah sindrom West, sindrom Lennox-Gastaut dan epilepsi mioklonik.

Menurut (Purnama, 2009), setiap makhluk hidup dituntut untuk memenuhi kebutuhan dasarnya yang berguna untuk kelangsungan hidupnya. Salah satunya adalah tidur. Tidur merupakan suatu proses aktif, bukan hanya sekedar hilangnya keadaan terjaga. Tingkat aktivitas otak tidak menurun selama tidur (Sherwood, 2016). Terdapat beberapa faktor yang mempengaruhi individu memperoleh tidur yang cukup, di antaranya adalah kuantitas tidur dan kualitas tidur. Kualitas tidur adalah suatu kondisi yang dijalani oleh seseorang sehingga mendapatkan kesegaran dan kebugaran saat terbangun dari tidurnya, sedangkan kuantitas tidur merupakan jumlah jam tidur normal yang diperlukan seseorang sesuai dengan kebutuhan tidurnya (Fenny \& Supriatmo, 2016).

Abnormalitas rekaman electro-encephalograph (EEG) pada kejang biasa akan terlihat berupa gelombang tajam atau lancip atau biasa disebut interictal epileptiform discharges (IEDs). Tidur diatur oleh beberapa mekanisme dan beberapa mekanisme tersebut mempengaruhi ekspresi dari kejang. Pada fase tidur non-Rapid Eye Movement, nukleus thalamus memfasilitasi sinkronisasi kortikal ke korteks. Proses ini yang dapat menyebabkan aktivasi bangkitan kejang fokal, dengan begitu fase tidur non-Rapid Eye Movement memberikan pengaruh terhadap efek kejang (Barone \& Chokroverty, 2017)

\section{Metode}

Metode yang digunakan adalah studi literatur dari 2 jurnal nasional dan internasional. Menggunakan metode traditional review dan tertiary study. Metode ini mengkaji dari berbagai jurnal terkait kualitas tidur dan epilepsi yang telah diterbitkan sebelumnya. Hal ini bertujuan untuk memberikan ringkasan berupa publikasi yang relevan dan meningkatkan pemahaman terkini.

\section{Hasil Dan Pembahasan}

Dari hasil dari traditional review dan tertiary study yang telah dilakukan didapatkan kualitas tidur yang tidak baik akan meningkatkan resiko kejadian kejang pada pasien epilepsi. Pada penelitian (Haut et al., 2007) yang menilai beberapa faktor yang berhubungan terhadap pencetus kejadian kejang pada analisis univariat mendapatkan hasil yaitu hari dengan stres yang rendah akan meningkatkan risiko kejang pada hari berikutnya $(\mathrm{OR}=1.3 ; 95 \% \mathrm{CI} 1.0,1.7)$ dan hari dengan stres yang tinggi $(\mathrm{OR}=1.6 ; 95 \% \mathrm{CI}$ 1.2, 2.1). Memperlakukan stres sebagai variabel kontinu, setiap poin dalam 10 poin skala stres dihubungkan dengan peningkatan odds ratio pada kejang di hari berikutnya yaitu 1.12 (95\% CI 1.07, 1.17). Hasil yang didapat juga tidak berbeda jauh untuk kecemasan. Hari dengan tingkat kecemasan yang rendah berhubungan dengan peningkatan risiko kejang pada hari berikutnya (OR $=1.5 ; 95 \%$ CI $1.2,1.9$ ) sedangkan untuk tingkat kecemasan yang tinggi (OR $=2.0 ; 95 \%$ CI 1.4, 2.6). Memperlakukan kecemasan sebagai variabel kontinu, setiap poin dalam 10 poin skala stres dihubungkan dengan peningkatan odds ratio pada kejang di hari berikutnya yaitu 1.13 (95\% CI 1.08, 1.18). Meningkatnya waktu tidur mempengaruhi penurunan kejadian kejang pada satu $(\mathrm{OR}=0.91 ; 95 \% \mathrm{CI} 0.86$, $0.96)$ dan dua (OR $=0.89 ; 5 \%$ CI 0.81, 0.97) malam sebelum kejang.

Model 1 : Pencetus kejang. Analisis multivariat terhadap pencetus yang diketahui dan pencetus yang dicurigai terhadap kejadian kejang. Variabel yang signifikan adalah waktu tidur serta stres dan kecemasan. Variabel yang kurang signifikan adalaha umur $(p=0.29)$, 
jenis kelamin $(\mathrm{p}=0.39)$, alcohol $(\mathrm{p}=0.76)$, pengobatan yang gagal $(\mathrm{p}=0.85)$, dan menstruasi $(p=0.50)$. Untuk setiap penambahan jam tidur dari malam sebelumnya, odds ratio terhadap kejang di hari berikutnya berkurang menjadi 0.91 (95\% CI: $0.82,0.99$ ). Karena batas atas CI tidak termasuk 1, hal ini menunjukan statistik yang signifikan efek protektif dari meningkatnya waktu tidur. Stres dan kecemasan secara signifikan berhubungan dengan meningkatnya risiko kejadian kejang pada hari berikutnya. Setiap peningkatan 1 poin stres pada skala 10 poin berpengaruh dengan OR kejang 1.06 (95\% CI 1.01, 1.12). Peningkatan 1 poin kecemasan pada skala 10 poin berpengaruh dengan odds ratio kejang 1.07 (95\% CI 1.02, 1.12).

Model 2: Peran prediksi kejang sendiri. Tingginya tingkat stres, cemas dan tidur berhubungan dengan tingginya kemungkinan prediksi positif dari subjek tersebut $(\mathrm{p}<$ 0.0001 untuk model efek campuran). Oleh karena itu, pada model regresi sekunder multivariat, termasuk subjek prediksi sendiri (variabel dichotomous), untuk menilai peran pencetus pada hasil laporan subjek. Variabel yang masih tetap di model prediksi diri sendiri $(\mathrm{OR}=3.7 ; 95 \%$ CI 1.8, 7.2) dan waktu tidur pada malam $(\mathrm{OR}=0.90 ; 95 \%$ CI 82, 0.99). Stres dan kecemasan tidak terlalu signifikan. Ketika prediksi sendiri dimasukkan ke dalam model, hanya waktu tidur yang tetap memberikan kontribusi independen secara signifikan. Pada penelitian lain juga tentang tidur dan epilepsi yang fokus pada hubungan jam dan epilepsi, didapat bahwa seseorang yang kekurangan tidur pada pukul 8 malam sampai 8 pagi dapat mengaktivasi kejang. Gowers mencatat 21\% dari 850 pasien mengalami kejang pada malam hari, $42 \%$ pada siang hari dan $37 \%$ pada malam atau siang hari (Gowers WR, 1881)

\section{Simpulan Dan Saran}

Epilepsi merupakan kejadian gangguan neurologik yang sering kita temui. Resiko kejadian kejang pada pasien epilepsi dapat disebabkan oleh ketidakpatuhan terhadap pengobatan namun ada beberapa faktor lain yang juga dapat meningkatkan faktor risiko kejang pada pasien epilepsi seperti cemas, stress, alkohol, prediksi kejang sendiri, dan waktu tidur. Ditulis secara ringkas tetapi menggambarkan substansi hasil pengabdian dan saran atau rekomendasi untuk kegiatan pengabdian berikutnya.

\section{Daftar Rujukan}

A. Prayitno. (2015). Gangguan Pola Tidur pada Kelompok Usia Lanjut dan Penatalaksanaannya. Jurnal Kedokteran Trisakti. https://doi.org/10.1177/0898264314523448

Barone, D. A., \& Chokroverty, S. (2017). Neurologic Diseases and Sleep. In Sleep Medicine Clinics. https://doi.org/10.1016/j.jsmc.2016.10.007

Deliana, M. (2016). Tata Laksana Kejang Demam pada Anak. Sari Pediatri. https://doi.org/10.14238/sp4.2.2002.59-62

Fenny, \& Supriatmo. (2016). Kualitas Tidur Dan Prestasi Belajar Pada Mahasiswa Fakultas Kedokteran. Jurnal Kedokteran, 5(3), 140-147.

Fisher, R. S., Van Emde Boas, W., Blume, W., Elger, C., Genton, P., Lee, P., \& Engel, J. (2005). Epileptic seizures and epilepsy: Definitions proposed by the International League Against Epilepsy (ILAE) and the International Bureau for Epilepsy (IBE). In Epilepsia. https://doi.org/10.1111/j.0013-9580.2005.66104.x

Gardiner, M. (2012). The epilepsies. In Neurogenetics: A Guide for Clinicians. https://doi.org/10.1017/CB09781139087711.004

Gowers WR. (1881). Epilepsy and other chronic convulsive disorders. Churchill.

Haut, S. R., Hall, C. B., Masur, J., \& Lipton, R. B. (2007). Seizure occurrence: Precipitants and prediction. Neurology, 69(20), 1905-1910.

Dansen Frans Louise Draven Rudyanto, Effect of Sleep Quality on the Incidence of Seizures in Epilepsy Patients 
https://doi.org/10.1212/01.wnl.0000278112.48285.84

Maganti, R., Hausman, N., Koehn, M., Sandok, E., Glurich, I., \& Mukesh, B. N. (2006). Excessive daytime sleepiness and sleep complaints among children with epilepsy. Epilepsy and Behavior. https://doi.org/10.1016/j.yebeh.2005.11.002

Nur'aini, N., Sofyani, S., Supriatmo, S., \& Lubis, I. Z. (2014). Comparing sleep disorders in urban and suburban adolescents. Paediatrica Indonesiana, 54(5), 299. https://doi.org/10.14238/pi54.5.2014.299-304

PERDOSSI. (2014). Pedoman Tatalaksana Epilepsi PERDOSSI. In Universitas Airlangga.

Piperidou, C., Karlovasitou, A., Triantafyllou, N., Terzoudi, A., Constantinidis, T., Vadikolias, K., Heliopoulos, I., Vassilopoulos, D., \& Balogiannis, S. (2008). Influence of sleep disturbance on quality of life of patients with epilepsy. Seizure. https://doi.org/10.1016/j.seizure.2008.02.005

Purnama, P. (2009). Hubungan tingkat kecemasan dan gangguan pola tidur pada pasien pertama kali dirawat inap di ruang perawatan umum Rumah Sakit Pusat Angkatan Darat Gatot Subroto Jakarta.

Sherwood, L. (2016). Human physiology from cells to systems Ninth Edition. In Appetite. https://doi.org/10.1016/j.appet.2008.10.006

Shorvon, S. (2011). The treatment of status epilepticus. Current Opinion in Neurology. https://doi.org/10.1097/WCO.0b013e3283446f31

Silbernagl, S., \& Lang, F. (2019). Color Atlas of Pathophysiology. In Color Atlas of Pathophysiology. https://doi.org/10.1055/b-005-148940

WHO. (2019). Epilepsy. Epilepsy; WHO. 